Jurnal Kejaora: Jurnal Kesehatan Jasmani dan Olah Raga

ISSN: 2541-5042 (Online)

ISSN: 2503-2976 (Print)

Volume 5 Nomor 2, Edisi November 2020

\title{
POCKET BOOK DEVELOPMENT MOBILE LEARNING-IOT (INTERNET OF THINKING) BERBASIS ANDROID TENTANG SINYAL-SINYAL WASIT BOLA VOLI KOTA KEDIRI
}

\author{
Puspodari' ${ }^{1}$ Nur Ahmad Muharram² \\ 1,2 Universitas Nusantara PGRI Kediri \\ E-mail: puspodari@unpkediri.ac.id11, nur.ahmad1988@unpkediri.ac.id² \\ DOI: https://doi.org/10.36526/kejaora.v5i2.1007
}

\begin{abstract}
ABSTRAK
Tujuan dari penelitian ini adalah mengembangkan sebuah pocket book mobile learning berbasis android didalamnya berisi tentang materi sinyal wasit, khususnya dalam penelitian ini yaitu wasit yang berada di Kota Kediri. Dengan ini diharapkan para wasit lebih bersemangat memimpin jalannya pertandingan dan mengurangi tingkat kesalahan dalam mempimpin pertandingan. Penelitian ini menggunakan metode research and development, dimana didalamnya terdapat analisis kebutuhan dan menggunakan metode wawancara yang digunakan untuk melihat masalah yang sering terjadi tentang sinyal-sinyal wasit bola voli di Kota Kediri. Setelah melakukan wawancara didapat hasil dilapangan yaitu belum menggunakan pocket book tentang sinyal-sinyal wasit yang berbasis mobile learning. Dari analisis kebutuhan ini dihasilkan evaluasi dari ahli dan uji coba yang disajikan pada bagian ini. Untuk data dari ahli itu sendiri meliputi saran dan hasil evaluasi dari 2 orang yang ahli dibidang IT khususnya pada pembelajaran, 3 Orang Desain Grafis, 5 Orang ahli dibidang perwasitan dan 5 orang ahli di dunia bola voli. Dari hasil evaluasi dihasilkan data kuantitatif yang berupa prosentase dan menunjukkan kelayakan produk yang mempunyai kategori baik sekali sehingga bisa dikatakan sudah memenuhi kriteria jika ingin dipergunakan, yaitu sebesar $95 \%$. Berdasarkan hasil uji coba skala kecil dan skala besar terkait dengan pengembangan pocket book tentang sinyal-sinyal perwasitan bola voli terdapat $93 \%$ dalam uji skala kecil dan menunjukkan bahwa produk ini layak untuk digunakan atau dalam kategori baik sekali. Sedangkan untuk uji skala besar berada pada kategori baik sekali atau jika di prosentasekan yaitu sebesar $97 \%$ tentang sinyal-sinyal wasit bola voli.
\end{abstract}

Kata Kunci: Sinyal Bola Voli, Pengembangan, Buku Saku, Wasit Bola Voli, Belajar Jaringan

\section{PENDAHULUAN}

Menurut Satyaputra \& Aritonang (2014) bahwa penggunaan android dapat berupa aktifitas browsing, e-mail, bermain game, bahkan sebagai media untuk menunjang program latihan. Dengan begitu media pembelajaran khususnya bola voli terkait dengan sinyal wasit yang berbasis mobile learning sangat efektif dan efisien karena sudah banyak digunakan oleh masyarakat luas. Untuk menindaklanjuti tentang ide atau gagasan ini maka peneliti melakukan studi pendahuluan tentang perwasitan yang berupa wawancara dan observasi. Berdasarkan hasil yang didapat melalui observasi dan berupa wawancara terhadap praktisi olahraga khususnya bola voli di kota kediri didapat fakta bahwa seringnya wasit bola voli yang masih melakukan kesalahan didalam memimpin jalannya suatu pertandingan.

Dari observasi yang didapat bisa disimpulkan bahwa seringnya wasit dalam mengambil keputusan sering tidak sesuai dengan peraturan pertandingan bola voli. selain itu, pemberian sinyal-sinyal juga sering tidak sesuai dengan peraturan pertandingan. Hal ini juga berupa fakta yang ada dilapangan dan didukung oleh hasil analisis kebutuhan yang telah dilakukan peneliti. Berdasarkan hasil analisis kebutuhan kepada anggota wasit bola voli di Kota Kediri didapatkan $80 \%$ belum pernah mendapatkan materi tentang sinyal-sinyal perwasitan bola voli dalam kegiatan latihan rutin, $79 \%$ belum pernah mendapatkan program latihan yang variatif, $46 \%$ responden membutuhkan program latihan tentang sinyal-sinyal wasit secara 
Jurnal Kejaora: Jurnal Kesehatan Jasmani dan Olah Raga

ISSN: 2541-5042 (Online)

ISSN: 2503-2976 (Print)

Volume 5 Nomor 2, Edisi November 2020

lengkap dan variatif. Untuk kesukaan terhadap jenis produk tentang sinyal-sinyal wasit bola voli, $17 \%$ menyukai VCD Pembelajaran, $72 \%$ menyukai dalam bentuk aplikasi android, dan 11\% menyukai buku cetak. Berdasarkan hasil analisis kebutuhan yang telah dilakukan, dapat ditarik kesimpulan bahwa masih banyak wasit bola voli yang sama sekali mendapatkan program latihan yang inovatif, sedangkan tentang sinyal sinyal wasit juga belum pernah didapat atau belum diberikan. Dari sini lah muncul masalah yang berdampak pada kepemimpinan wasit didalam memimpin jalannya suatu pertandingan. Dalam hal ini responden lebih menyukai tentang sinyal sinyal wasit bola voli yang dikemas dalam sebuah aplikasi.

Dengan demikian, maka dapat dilakukan penelitian dan pengembangan untuk menghasilkan produk berupa aplikasi buku saku tentang signal wasit bola voli yang dikembangkan dengan menggunakan sistem android. Salah satu pemanfaatan pocket book mobile learning adalah sebagai media untuk pemberian materi dan latihan tentang signal-signal dan peraturan permainan pada wasit bola voli yang selama ini belum sepenuhnya tersampaikan di Kota Kediri. Pelatih dalam hal ini adalah Komisi Wasit, tidak memiliki media yang efisien dalam melaksanakan program latihan. Sementara wasit membutuhkan media tersebut untuk menunjang kegiatan latihan. Sehingga materi yang disampaikan lebih mudah dipahami dan diaplikasikan dalam pertandingan bola voli oleh para wasit bola voli di Kota Kediri.

Adanya fenomena dan konsep yang telah dijelaskan, menjadi alasan dan latar belakang peneliti untuk melakukan penelitian dan pengembangan guna meningkatkan profesionalitas dan kinerja wasit bola voli di Kota Kediri ketika melaksanakan tugas memimpin sebuah pertandingan bola voli. Menurut Muharram (2019) "singnal wasit ini digunakan untuk membantu wasit untuk tidak sering melakukan kesalahan". Dalam upaya meningkatkan profesionalitas dan kinerja wasit tersebut, peneliti melakukan penelitian dan pengem- bangan dengan judul "Pengembangan pocket book mobile learning

IOT(internet of thinking) Berbasis Android Tentang sinyal-sinyal Wasit Bola voli Untuk Wasit Bola voli Di Kota Kediri".

Tujuan penelitian ini adalah mengembangkan pocket book mobile learning yang berisikan materi tentang sinyalsinyal wasit bola voli yang diharapkan mampu untuk membantu dalam proses pemahaman sinyal-sinyal perwasitan bola voli yang terdapat tulisan dan gambar animasi gerakan yang benar, rinci dan dapat dipahami oleh wasit bola voli di Kota Kediri. Sehingga, pocket book mobile learning perwasitan bola voli tersebut dapat dijadikan sebagai media untuk mengoptimalkan latihan, sehingga wasit bola voli di Kota Kediri. Wasit bola voli dapat menjaga dan meningkatkan profesionalitas dan kinerja melalui latihan dan pemahaman materi yang ada di dalam pocket book mobile learning perwasitan bola voli. Sehingga, wasit bola voli dapat melaksanakan tugas memimpin sebuah pertandingan bola voli dengan lebih baik dan profesional. Langkah-langkah yang digunakan dalam penelitian dan pengembangan pocket book mobile learning perwasitan bola voli mengacu pada pendapat (Borg \& Gall, 1983) tentang penelitian dan pengembangan yang telah dimodifikasi oleh peneliti yakni (1) Melakukan analisis kebutuhan melalui observasi lapangan, wawancara, dan penyebaran angket, (2) Mengembangkan produk awal, (3) Validasi ahli. (4) Revisi produk awal berdasarkan evaluasi para ahli, (5) Uji coba lapangan meliputi uji kelompok kecil dan uji kelompok besar, (6) Revisi produk berdasarkan hasil uji coba kelompok kecil dan uji coba kelompok besar, dan (7) Hasil akhir produk pengembangan dari hasil revisi produk akhir.

\section{METODE}

Penelitian ini menggunakan metode penelitian dan pengembangan (research and development). Instrumen dalam penelitian ini adalah model tes keterampilan tendangan ap hurigi yang disusun oleh peneliti dan disetujui oleh tim ahli. Data yang diperoleh akan dibagi menjadi 2 bagian yaitu data kualitatif yang merupakan saran dan kritik oleh ahli biomekanika olahraga, ahli tes dan pengkuran, pelatih dan wasit. Sedangkan 
Jurnal Kejaora: Jurnal Kesehatan Jasmani dan Olah Raga

ISSN: 2541-5042 (Online)

ISSN: 2503-2976 (Print)

Volume 5 Nomor 2, Edisi November 2020

data hasil angket yang diberikan akan diolah menjadi data kuantitaif. Teknik analisis yang digunakan untuk data kuantitatif adalah teknik analisis statistik deskriptif. Untuk itu dilakukan analisis menggunakan perhitungan statistik dengan langkah-langkah menggunakan uji reliabilitas dan uji validitas. Menurut Sugiyono (2013) langkah-langkah peneltian dalam penelitian dan penembangan (research and development) terdiri dari (1) potensi masalah, (2) pengumpulan data, (3) desain produk, (4) Validasi desain, (5) revisi desain, (6) ujicoba produk, (7) revisi produk, (8) ujicoba pemakaian, (9) revisi produk. Penelitian ini dilakukan di Kota Kediri pada bulan Juli 2020 dengan populasi sejumlah 50 wasit bola voli kemudian pengambilan Sampel adalah sebagian atau wakil dari populasi yang diteliti (Arikunto, 2010). Teknik sampling yang digunakan adalah purposive sampling, yaitu teknik pengambilan sampel dengan menggunakan kriteria tertentu. sehingga didapat 35 wasit yang dijadikan sampel. Pada tahap ini teknik pengumpulan data yang digunakan adalah menganalisis perkembangan kinerja wasit kota kediri.

\section{HASIL DAN PEMBAHASAN}

Produk hasil pengembangan yang telah dilaksanakan peneliti berupa media pocket book mobile learning tentang sinyalsinyal wasit bola voli. Pengembangan produk dalam penelitian ini dilakukan sebagai upaya untuk meningkatkan kemampuan psikomotor wasit bola voli. Keberhasilan pengembangan ranah kognitif juga akan berdampak positif terhadap perkembangan ranah psikomotor (Syah, 2005). Pocket Book Mobile learning berbasis android dapat digunakan sebagai media yang layak untuk pembelajaran yang berfokus pada aspek kognitif. Dengan demikian, penggunaan media pocket book mobile learning berbasis android diharapkan mampu untuk mengembangkan psikomotor wasit bola voli di Kota Kediri.

Penggunaan media dalam pembelajaran sejalan dengan pendapat Dwiyogo (2008) yang menyatakan bahwa media adalah alat atau cara yang digunakan sebagai perantara untuk menyampaikan informasi (pesan) agar dapat diterima oleh penerima informasi sepenuhnya.

Penggunaan media dalam proses pembelajaran, dapat menarik dan memperbesar perhatian pebelajar terhadap materi yang disajikan. Hal ini menunjukkan bahwa media pembelajaran dapat menumbuhkan kegairahan belajar dalam mempelajari materi yang disajikan. Produk yang dikembangkan merupakan aplikasi buku saku perwasitan bola voli berbasis android. Media pocket book mobile learning perwasitan bola voli merupakan salah satu alternatif layanan pembelajaran yang dapat dilaksanakan kapanpun dan dimanapun. Pemikiran dalam mengembangkan media ini didasari oleh alasan-alasan pokok yang dikemukakan oleh Darmawan (2011) yaitu: (1) dapat digunakan kapanpun dan dimanapun, (2) cakupan luas, dan (3) terintegrasi dengan sistem lainnya. Media pocket book mobile learning perwasitan bola voli diwujudkan dalam versi offline yang dapat dilakukan dan dimulai hanya dengan melakukan satu kali pemasangan dan tidak mbutuhkan koneksi internet dalam penggunaannya (stand alone). Penggunaan media pembelajaran dalam usaha memberikan hasil belajar wasit bola voli yang tinggi memiliki peran yang sangat besar. Salah satu contoh tentang sinyal didalam bola voli yaitu tentang servis, seperti yang di jelaskan dalam peraturan (FIVB, 2012) "Moreover, it is the only action of the game preceded by a period of 8 seconds from the first referee's signal for serve". Sering dilakukan kejadian kejadian didalam servis yang wasit tidak mengetahuinya apakah itu terjadi foul tau tidak karena jaraknya yang tidak berada didekat wasit, sebagai contoh servis untuk pria, menurut Kitsiou (2020) "This change reflected the evolution of the serve skill and probably the attention given by the men for the performance improvement".

Melalui media pembelajaran, potensi indra pembelajaran dapat diakomodasi sehingga hasil belajar akan meningkat. Hal ini sejalan dengan pendapat Rusman, et al. (2013) yang menyatakan bahwa salah satu aspek yang diunggulkan mampu meningkatkan hasil belajar adalah bersifat multimedia, yaitu gabungan dari berbagai unsur media seperti teks, gambar, dan animasi. Adanya unsur media seperti teks, 
Jurnal Kejaora: Jurnal Kesehatan Jasmani dan Olah Raga

ISSN: 2541-5042 (Online)

ISSN: 2503-2976 (Print)

Volume 5 Nomor 2, Edisi November 2020

gambar dan animasi akan mengakomodasi indra pebelajar dengan perangsangan melalui teks, gambar dan animasi dalam media pembelajaran. Media yang dikembangkan juga menyediakan petunjuk penggunaan aplikasi yang tercetak. Ini dimaksudkan sebagai panduan pengguna sebelum menggunakan produk. Dalam petunjuk penggunaan aplikasi dijelaskan tentang rasional pengembangan produk, tujuan, sasaran dan prosedur sebelum menggunakan aplikasi sebagai upaya untuk meningkatkan kemampuan psikomotor wasit bola voli. Di dalam petunjuk penggunaan juga dilengkapi dengan penjelasan menu dan tombolnavigasi, spesifikasi sistem, dan penjelasan isi sebagai acuan dalam menggunakan produk. Materi yang digunakan sebagai pesan dalam aplikasi perwasitan bola voli diwujudkan dalam bentuk gambar yang disertai dengan analisis geraknya.

Dalam aplikasi perwasitan bola voli juga terdapat peraturan permainan bola voli yang ditampilkan dengan format PDF. Aplikasi perwasitan bola voli ini didesain dan disusun selayak mungkin untuk menjadi media yang dapat digunakan sebagai upaya untuk meningkatkan kemampuan psikomotor wasit bola voli karena kejelasan dan kemenarikan desain produk berpengaruh pada pengguna dalam menggunakan aplikasi. Hal ini diperkuat oleh pendapat Sutopo (2012) bahwa desain visual yang baik memberikan pengaruh yang kuat pada kejelasan, konsistensi, dan estetis produk yang dikembangkan. Media pocket book mobile learning perwasitan bola voli memiliki karakteristik (1) Aplikasi buku saku perwasitan bola voli memiliki tujuan untuk meningkatkan kemampuan psikomotor wasit bola voli, (2) Produk aplikasi buku saku perwasitan bola voli terdiri dari 2 komponen yaitu petunjuk penggunakan aplikasi tercetak dan aplikasi buku saku perwasitan bola voli, (3) Petunjuk penggunaan aplikasi berisi penjelasan tentang rasional pengembangan produk, tujuan, sasaran dan prosedur sebelum melakukan instalasi aplikasi. Dalam petunjuk penggunaan aplikasi juga dilengkapi dengan penjelasan menu dan tombol navigasi, spesifikasi sistem, dan penjelasan

isi sebagai acuan dalam menggunakan produk, (4) Aplikasi buku saku perwasitan bola voli berisikan signal-signal yang digunakan oleh wasit bola voli dalam sebuah pertandingan bola voli dan disertai dengan analisis geraknya.

Dalam aplikasi buku saku perwasitan bola voli juga terdapat peraturan permainan bola voli yang diwujudkan dengan menggunakan format PDF, (5) Produk aplikasi pocket book mobile learning tentang perwasitan bola voli dikembangkan berdasarkan jawaban variabel kebutuhan wasit bola voli di Kota Kediri. Untuk mendapatkan hasil terbaik terhadap pengembangan pocket book mobile learning perwasitan bola voli, peneliti bekerja sama dengan beberapa ahli diantaranya ahli media pembelajaran, ahli desain grafis, ahli wasit bola voli, dan ahli olahraga bola voli. Hal ini penting dilakukan agar produk yang dikembangkan menjadi produk yang layak digunakan oleh calon pengguna. Uji coba penelitian dalam tahap ini dilakukan dalam 2 tahap, yaitu uji ahli pada tahap preliminary field testing dan uji coba keseluruhan produk pada tahap main field test. Uji ahli dalam penelitian dan pengembangan pocket book mobile learning perwasitan bola voli melibatkan ahli media pembelajaran, ahli desain grafis, ahli wasit bola voli, dan Praktisi olahraga khusunya bola voli.

Hasil pengumpulan data melalui hasil analisis kebutuhan, evaluasi ahli dan uji coba disajikan dalam bagian ini. Data hasil evaluasi para ahli meliputi saran dan hasil evaluasi 2 orang ahli IT khusus media pembelajaran, 3 orang ahli desain grafis, 5 orang ahli wasit bola voli, dan 5 orang praktisi olahraga bola voli. Data hasil uji coba kelompok kecil dan uji coba kelompok besar diperoleh dari jawaban wasit di Kota Kediri sebagai subjek penelitian terhadap instrumen pengumpulan data yang berupa kuesioner yang menunjukkan bahwa produk pengembangan media pocket book mobile learning tentang sinyal-sinyal wasit bola voli yang diwujudkan dalam aplikasi berbasis android termasuk dalam kategori yang sangat layak untuk digunakan. Berdasarkan data dari tinjauan para ahli, diperoleh beberapa saran yang digunakan sebagai acuan untuk merevisi rancangan 
Jurnal Kejaora: Jurnal Kesehatan Jasmani dan Olah Raga

ISSN: 2541-5042 (Online)

ISSN: 2503-2976 (Print)

Volume 5 Nomor 2, Edisi November 2020

produk. Revisi produk penting dilakukan agar produk awal yang dikembangkan menjadi lebih sempurna dan menarik untuk digunakan oleh calon pengguna. Hal ini sejalan dengan pendapat Dwiyogo (2008) yang menyatakan bahwa media pembelajaran yang menarik akan merangsang dan menstimulus pebelajar untuk lebih termotivasi dalam menyerap informasi tentang sesuatu.

Adapun revisi yang pertama terkait dengan pengembangan pocket book mobile learning perwasitan bola voli adalah tampilan pada menu peraturan. Perbaikan tampilan dalam menu peraturan permainan akan memberikan nilai tambah terhadap kemenarikan produk. Perbaikan yang dilakukan adalah dengan mendesain ulang tampilan menu peraturan permainan dengan memberikan warna dan gambar yang sesuai dengan tema. Hal ini sejalan dengan pendapat Hartanto (2013) yang menyatakan bahwa "Otak manusia itu lebih suka dengan segala sesuatu yang bergambar dan berwarna, karena gambar bisa memiliki sejuta arti sedangkan warna akan membuat segala sesuatu menjadi lebih hidup". Pendapat Hartanto tersebut memperkuat keunggulan produk tentang kejelasan komponen produk sebagai media pembelajaran. Penggunaan gambar dan warna pada desain produk telah memberikan kemenarikan pada produk sehingga produk disukai oleh pengguna. Revisi yang kedua adalah simbol-simbol pada aplikasi yang diperjelas. Simbol-simbol dalam aplikasi yang diperjelas akan memberikan kemudahan kepada pengguna dalam menggunakan produk Perbaikan simbol dan navigasi pada aplikasi dilakukan. Menurut Thorn dalam Rusman (2013) bahwa sebuah program harus dirancang sesederhana mungkin sehingga pebelajar tidak perlu belajar komputer lebih dulu.

Oleh karena itu, simbol dan navigasi dalam aplikasi harus didesain dengan jelas agar memudahkan pengguna dalam menggunakan produk. Revisi ketiga adalah pembuatan "Manual" untuk petunjuk penggunaan aplikasi. Pemberian petunjuk penggunaan aplikasi manual akan disertakan untuk mempermudah pemahaman pengguna sebelum menggunakan produk. Revisi keempat adalah pencantuman spesifikasi sistem dalam petunjuk penggunaan manual. Spesifikasi sistem akan dicantumkan ke dalam petunjuk penggunaan aplikasi bermanfaat sebagai acuan pengguna sebelum menginstal aplikasi. Uji coba keseluruhan produk melibatkan 35 wasit bola voli di Kota Kediri selaku calon pengguna produk yang dilaksanakan dalam 2 tahap yaitu uji coba kelompok kecil dan uji coba kelompok besar. Pelaksanaan uji coba produk diawali dengan pemberian materi dan penerapan produk pengembangan melalui praktek selama 6 kali pertemuan pada uji coba kelompok kecil dan kelompok besar. Pemberian materi selama 6 kali pertemuan dilakukan agar calon pengguna produk dapat sepenuhnya memahami isi materi yang ada dalam produk. Hal ini sejalan dengan pendapat Setyosari (2012) bahwa pembelajaran yang dirancang untuk mencapai suatu tujuan belajar tertentu, maka pembelajaran itu mungkin akan lebih efektif. Dalam kegiatan pembelajaran, media pembelajaran sangat menentukan efektifitas dan efisiensi pencapaian tujuan belajar. Tanpa adanya media pembelajaran, proses belajar tidak akan pernah terjadi (Sihkabuden, 2011). Dengan menggunakan buku saku mobile learning perwasitan bola voli, diharapkan kemampuan psikomotor wasit bola voli dapat ditingkatkan.

Pocket book mobile learning perwasitan bola voli efektif digunakan sebagai alternatif media penunjang latihan wasit bola voli. Rusman, et al. (2013) menyatakan bahwa efektifitas pembelajaran menggunakan information communication technology (ICT) atau dengan menggunakan media lebih baik dibanding dengan pembelajaran konvensional. Pendapat Rusman, dkk tersebut memperkuat bahwa pocket book mobile learning perwasitan bola voli efektif digunakan oleh wasit bola voli dalam menunjang kegiatan latihan. Subjek coba kelompok kecil melibatkan 15 orang dan kelompok besar melibatkan 20 orang yang memiliki karakteristik sebagai wasit bola voli di Kota Kediri dengan menggunakan random sampling karena dilakukan secara acak tanpa memperhatikan strata yang ada dalam populasi. 
Jurnal Kejaora: Jurnal Kesehatan Jasmani dan Olah Raga

ISSN: 2541-5042 (Online)

ISSN: 2503-2976 (Print)

Volume 5 Nomor 2, Edisi November 2020

Data kuantitatif hasil dari uji coba keseluruhan produk menunjukkan bahwa media pocket book mobile learning tentang sinyal-sinyal wasit bola voli termasuk dalam kategori yang sangat layak untuk digunakan. Data kualitatif didapatkan dari uji coba produk berupa saran terkait pengembangan produk Pocket Book Mobile learning perwasitan bola volil bahwa perbaikan terhadap aplikasi yang menjadi kendala beberapa android sehingga tidak bisa menampilkan isi dari aplikasi perlu dilakukan agar pesan yang ada dalam aplikasi dapat ditampilkan secara menyeluruh. Perbaikan selanjutnya yang dilakukan adalah pemberian efek zoom pada tampilan halaman pembuka untuk memperjelas tulisan sehingga pengguna lebih mudah memahami isi dalam halaman pembuka. Keunggulan produk ini sebagai salah satu alternatif media yang layak digunakan oleh wasit bola voli adalah (1) Materi signal wasit bola voli dikemas dalam satu bentuk aplikasi simple dan didesain semenarik mungkin sehingga memiliki nilai hiburan, (2)Tampilan gambar, font, kejelasan font, kemenarikan font dan desain tampilan aplikasi lebih ditonjolkan sehingga menarik minat wasit untuk mempelajarinya, (3)Media pocket book mobile learning dapat digunakan sebagai media belajar mandiri, (4) Media pocket book mobile learning mudah dibawa kemana-mana sehingga bisa dipelajari kapanpun dan dimanapun, (5) Media buku saku mobile learning perwasitan bola voli berperan sebagai pelengkap, penguat, dan pengingat (reminder) tentang informasi sinyal-sinyal perwasitan bola voli karena di dalamnya berisi materi sinyal-sinyal perwasitan bola voli berdasarkan peraturan permainan PBVSI. Murniati (2012) menyatakan bahwa buku mobile learning memiliki kelebihan dalam hal accessibility, functionality, and cost-effectiveness.

Buku mobile learning menawarkan kemungkinan kreasi untuk perluasan akses pembelajaran. Konten buku mobile learning dapat selalu diakses tanpa menghiraukan waktu dan tempat, dapat dibaca pada smartphone yang mudah dibawabawa (portable). Pendapat Murniati (2012) tersebut menunjukkan bahwa produk pocket book mobile learning perwasitan bola voli dapat

menjadi media yang layak karena salah satu keunggulan buku saku mobile learning perwasitan bola voli adalah mudah dibawa kemana-mana sehingga bisa dipelajari kapanpun dan dimanapun. Pocket Book Mobile learning perwasitan bola voli juga didapatkan secara gratis sehingga pengguna tidak terbebani secara finansial. Keuntungan menggunakan produk buku saku mobile learning perwasitan bola voli juga hampir sama dengan keuntungan menggunakan mobile learning. Menurut Sutopo (2012) diantaranya: (1) Convenience. Penggunaan pocket book mobile learning perwasitan bola voli dapat diakses dari mana saja pada konten pembelajaran, (2) Collaboration. Pembelajaran dengan menggunakan pocket book mobile learning perwasitan bola voli dapat dilakukan setiap saat secara real time, bahkan sesaat sebelum pertandingan dimulai, (3) Portability. Buku saku mobile learning perwasitan bola voli dapat dengan mudah untuk dibawa kemanamana, (4) Compatibility.

Pembelajaran perwasitan bola voli dirancang untuk digunakan pada perangkat mobile, dan (5) Interesting. Pocket book mobile learning perwasitan bola voli didesain dengan menggunakan gambar animasi sehingga menarik untuk digunakan. Produk pengembangan pocket book mobile learning ini juga masih memiliki beberapa keterbatasan yang perlu untuk dikembangkan lebih lanjut. Keterbatasan tersebut adalah topik yang dikembangkan dalam produk ini terbatas pada peningkatan kemampuan psikomotor wasit bola voli di Kota Kediri. Keterbatasan selanjutnya adalah tahapan uji coba penelitian ini masih terbatas pada uji coba keseluruhan produk pada kelompok kecil.

Tabel 1. Data Hasil Evaluasi Ahli Media Pembelajaran

\begin{tabular}{llll}
\hline $\begin{array}{l}\text { Komponen } \\
\text { Produk }\end{array}$ & Skor & $\begin{array}{l}\text { Skor } \\
\text { Maks }\end{array}$ & \% \\
\hline Kemenarikan & 85,5 & 90 & $95 \%$ \\
\hline Kejelasan & 78 & 90 & $87 \%$ \\
\hline Ketepatan & 88 & 90 & $98 \%$ \\
\hline Kesesuaian & 89 & 90 & $99 \%$ \\
\hline Total Skor & 340 & 360 & $95 \%$ \\
\hline
\end{tabular}


Jurnal Kejaora: Jurnal Kesehatan Jasmani dan Olah Raga

ISSN: 2541-5042 (Online)

ISSN: 2503-2976 (Print)

Volume 5 Nomor 2, Edisi November 2020

Berdasarkan hasil evaluasi terhadap pengembangan media pocket book mobile learning perwasitan bola voli yang dilakukan oleh ahli media pembelajaran, didapatkan hasil akhir data kuantitatif berupa persentase kelayakan yang menunjukkan bahwa produk termasuk dalam kategori baik sekali dan layak untuk digunakan.

Tabel 2. Data Hasil Evaluasi Ahli Desain Grafis

\begin{tabular}{llll}
\hline $\begin{array}{l}\text { Komponen } \\
\text { Produk }\end{array}$ & Skor & $\begin{array}{l}\text { Skor } \\
\text { Maks }\end{array}$ & $\%$ \\
\hline Kemenarikan & 75 & 80 & $94 \%$ \\
\hline Kejelasan & 76 & 80 & $95 \%$ \\
\hline Ketepatan & 77 & 80 & $96 \%$ \\
\hline Kesesuaian & 79 & 80 & $99 \%$ \\
\hline Total Skor & 307 & 320 & $96 \%$ \\
\hline
\end{tabular}

Berdasarkan hasil evaluasi ahli terhadap pengembangan media pocket book mobile learning perwasitan bola voli yang dilakukan oleh ahli desain grafis, didapatkan hasil akhir data kuantitatif berupa persentase kelayakan yang menunjukkan bahwa produk termasuk dalam kategori baik sekali dan layak untuk digunakan.

Tabel 3. Data Hasil Evaluasi Ahli Wasit Bola voli

\begin{tabular}{lcll}
\hline $\begin{array}{l}\text { Komponen } \\
\text { Produk }\end{array}$ & Skor & $\begin{array}{l}\text { Skor } \\
\text { Maks }\end{array}$ & $\%$ \\
\hline Kesesuaian & 141,5 & 150 & $94 \%$ \\
\hline
\end{tabular}

Berdasarkan hasil evaluasi ahli terhadap pengembangan media pocket book mobile learning perwasitan bola voli yang dilakukan oleh ahli wasit bola voli, didapatkan hasil akhir data kuantitatif berupa persentase kelayakan yang menunjukkan bahwa produk termasuk dalam kategori baik sekali dan layak untuk digunakan.

Tabel 4. Data Hasil Evaluasi Ahli Praktisi Olahraga Bola voli

\begin{tabular}{lcll}
\hline $\begin{array}{l}\text { Komponen } \\
\text { Produk }\end{array}$ & Skor & $\begin{array}{l}\text { Skor } \\
\text { Maks }\end{array}$ & $\%$ \\
\hline Kesesuaian & 146 & 150 & $97 \%$ \\
\hline
\end{tabular}

Berdasarkan hasil evaluasi ahli terhadap pengembangan media pocket book mobile learning perwasitan bola voli yang dilakukan oleh ahli praktisi olahraga bola voli, didapatkan hasil akhir data kuantitatif berupa persentase kelayakan yang menunjukkan

bahwa produk termasuk dalam kategori baik sekali dan layak untuk digunakan. Materi yang digunakan pada produk pocket book mobile learning perwasitan bola voli sudah sesuai dengan peraturan permainan dari PBVSI. Hasil tersebut menunjukkan produk termasuk dalam katagori baik sekali, berarti pocket book mobile learning perwasitan bola voli dinyatakan tepat dan layak sebagai produk yang teruji, sehingga dapat disimpulkan bahwa media buku saku tentang sinyal-sinyal perwasitan bola voli dapat diuji cobakan kepada calon pengguna.

Tabel 5. Data Hasil Uji Coba Kelompok Kecil

\begin{tabular}{llll}
\hline $\begin{array}{l}\text { Komponen } \\
\text { Produk }\end{array}$ & Skor & $\begin{array}{l}\text { Skor } \\
\text { Maks }\end{array}$ & $\%$ \\
\hline Kemenarikan & 750 & 800 & $94 \%$ \\
\hline Kejelasan & 640 & 650 & $98 \%$ \\
\hline Ketepatan & 83 & 90 & $92 \%$ \\
\hline Kesesuaian & 81 & 90 & $90 \%$ \\
\hline Total Skor & 1554 & 1630 & $93 \%$ \\
\hline
\end{tabular}

Berdasarkan hasil uji coba produk terkait pengembangan media pocket book mobile learning perwasitan bola voli dalam kelompok kecil, didapatkan hasil akhir data kuantitatif berupa persentase kelayakan yang menunjukkan bahwa produk termasuk dalam kategori baik sekali dan layak untuk digunakan.

Tabel 6. Data Hasil Uji Coba Kelompok Besar

\begin{tabular}{llll}
\hline $\begin{array}{l}\text { Komponen } \\
\text { Produk }\end{array}$ & Skor & $\begin{array}{l}\text { Skor } \\
\text { Maks }\end{array}$ & \% \\
\hline Kemenarikan & 2900 & 3000 & $97 \%$ \\
\hline Kejelasan & 2450 & 2500 & $98 \%$ \\
\hline Ketepatan & 290 & 300 & $97 \%$ \\
\hline Kesesuaian & 285 & 300 & $95 \%$ \\
\hline Total Skor & 5925 & 6100 & $97 \%$ \\
\hline
\end{tabular}

Hasil uji coba produk dalam kelompok besar masuk pada katagori baik sekali, jadi produk pocket book mobile learning tentang sinyal-sinyal perwasitan bola voli sebagai produk yang teruji, tepat dan menarik untuk digunakan oleh wasit bola voli di Kota Kediri.

\section{KESIMPULAN}

Berdasarkan pengumpulan data melalui hasil analisis kebutuhan, evaluasi ahli dan uji coba disajikan dalam bagian ini. Data hasil evaluasi para ahli meliputi saran dan 
Jurnal Kejaora: Jurnal Kesehatan Jasmani dan Olah Raga

ISSN: 2541-5042 (Online)

ISSN: 2503-2976 (Print)

Volume 5 Nomor 2, Edisi November 2020

hasil evaluasi 2 orang ahli media pembelajaran, 3 orang ahli desain grafis, 5 orang ahli wasit bola voli, dan 5 orang ahli praktisi olahraga bola voli. Data hasil uji coba kelompok kecil dan uji coba kelompok besar diperoleh dari jawaban wasit di Kota Kediri sebagai subjek penelitian terhadap instrumen pengumpulan data yang berupa kuesioner. Data pertama yang disajikan merupakan data kuantitatif berupa hasil pengisian instrumen evaluasi ahli media pembelajaran terkait pengembangan buku saku mobile learning perwasitan bola voli yang dipaparkan pada tabel yang ada dipembahasan.

\section{DAFTAR PUSTAKA}

Borg, W.R. \& Gall, M. D. (1983). Educational Research: An Introduction, Fourth Education. New York \& London: Longman.

Darmawan, D. (2011). Teknologi Pembelajaran. Bandung: PT Remaja Rosdakarya.

Dwiyogo, W. D. (2008). Aplikasi Teknologi Pembelajaran Media Pembelajaran Penjas \& Olahraga. Malang: Universitas Negeri Malang.

F.I.V.B. (2012). Official Volleyball Rules 20132016. F.I.V.B.

Hartanto, H. (2013). Keluarga Berencana dan Kontrasepsi. Jakarta: Pustaka Sinar Harapan.

Kitsiou, A., et al. (2020). Tendencies of the volleyball serving skill with respect to the serve type across genders. Jurnal of Physical Education and Sport (JPES), $564-570$.

Muharram, N. . \& Putra, R. P. (2019). Pengembangan Buku Saku Mobile Learning Berbasis Android Tentang Signal-Signal Wasit Bola voli Kota Kediri. Prosiding Seminar Nasional IPTEK Olahraga (SENALOG) 2 (1)

Murniati, A. (2012). Pemanfaatan E-Journal Dan E-Book Oleh Mahasiswa Di Lingkungan kultas Tarbiyah Dan Keguruan UIN SUSK Riau.

Rusman, et al. (2013). Metode-Metode Pembelajaran: Mengembangkan Profesionalisme Guru. Jakarta: PT RajaGrafindo Persada.

Setyosari, P. (2012). Metode Penelitian Pendidikan dan Pengembangan. Jakarta: Kencana.

Sihkabuden. (2011). Media Pembelajaran. Malang: Malang: FIP-UM.

Sugiyono. (2013). Metodologi Peneltian Pendidikan (Pendekatan Kuantitatif, Kualitatif dan R\&D). Bandung: Alfabeta.

Sutopo, A. H. (2012). Teknologi Informasi dan Komunikasi Dalam Pendidikan. Yogyakarta: raha IImu.

Syah, M. (2005). Psikologi Pendidikan dengan Pendekatan Baru. Bandung: Remaja Rosdakarya. 